\section{Total Nonstructural Carbohydrate Storage in Creeping Bentgrass Treated with Trinexapac-ethyl}

\author{
Sangwook Han \\ Gyeonggido Agricultural Research and Extension Services, 315 Kinsan-ri, \\ Taean-eup, Hwasung City, Gyeonggido 445-972, Republic of Korea
}

Thomas W. Fermanian, ${ }^{1}$ John A Juvik, and Louis A. Spomer
Departmental of Natural Resources and Environmental Sciences, University of
Illinois at Urbana-Champaign, 1102 South Goodwin Avenue, Urbana, IL 61801

Additional index words. TNC, photosynthates, PGR, turfgrass, Agrostis stolonifera

\begin{abstract}
Total nonstructural carbohydrates (TNC) are important for summer recuperation from injury for cool-season turfgrass. The objectives of this study were to determine if trinexapac-ethyl (TE) [4-(cyclopropyl-a-hydroxy-methylene)-3,5- dioxo-cyclohexanecarboxylic acid ethyl ester] affects TNC content and turf quality of a creeping bentgrass at various application frequencies and rates and to investigate any interactions between the effects of TE and traffic treatments on TNC content. Field experiments were conducted in 1995 and 1996 on a mature stand of 'Pennlinks' creeping bentgrass grown on a Flanagan silt loam soil maintained at a height of $1.9 \mathrm{~cm}$. Treatments included a single application $\left(0.28 \mathrm{~kg} \cdot \mathrm{ha}^{-1}\right)$ or repeat applications at $2\left(0.06 \mathrm{~kg} \cdot \mathrm{ha}^{-1}\right)$ or 4 (one at $0.28 \mathrm{~kg} \cdot \mathrm{ha}^{-1}$ and one at $0.09 \mathrm{~kg} \cdot \mathrm{ha}^{-1}$ ) week intervals during the first 8 weeks of each experiment. Treatments were arranged in a strip-plot design with TE applications as whole plots and traffic treatments as strip plots. Traffic treatments began at 2 weeks and 2 days after initial applications in 1995 and 1996, respectively and continued until the last evaluation date. Traffic treatments consisted of 4 passes of a $102.2 \mathrm{~kg}$ smooth roller, 2 days $^{\cdot}$ week $^{-1}$ in 1995 and 8 passes daily in 1996. A single aqueous extraction method was used for quantification of glucose, fructose, sucrose, and fructan. TNC was the total of all analyzed fractions. Single applications of TE at $0.28 \mathrm{~kg} \cdot \mathrm{ha}^{-1}$ significantly reduced turf quality for 4 weeks in both experiments. Sequential applications of TE at $0.06 \mathrm{~kg} \cdot \mathrm{ha}^{-1}$ exhibited reduced quality compared to the control at 4 and 8 weeks in 1995 and 2 weeks in 1996 . When TE was applied once at $0.28 \mathrm{~kg}^{-h^{-1}}$, there was a significant reduction in TNC from 4 to 8 weeks after treatment. In 1996 when TE applications were repeated at 2 and 4 week intervals at 0.06 and $0.09 \mathrm{~kg} \cdot \mathrm{ha}^{-1}$, a reduction of TNC from week 4 to week 14 was observed. After 14 weeks the TNC content showed incremental increases. There was no interaction effect between traffic treatments and TE applications in the verdure TNC in either year. In 1996, verdure TNC content was $6 \%$ to $17 \%$ lower in plots receiving traffic from weeks 4 to 18 . These results suggest that high rates of TE, either sequential or single applications, might reduce turf quality or carbohydrate content. While this study has not examined if this is detrimental, multiple TE applications at low rates may minimize any $\mathrm{TNC}$ reduction while providing effective growth suppression for extended periods.
\end{abstract}

Creeping bentgrass (Agrostis stolonifera Huds.) is a cool-season turfgrass commonly used in high maintenance areas like fairways (Beard, 2002). Frequent and regular mowing of bentgrass is an inevitable practice to maintain high quality turf. Where clippings are not collected they can sometimes reduce the quality of the playing surface (Beard, 2002). The plant growth regulator (PGR) trinexapac-ethyl (TE) can potentially reduce the quantity of clippings minimizing their impact on playability (Fagerness and Penner, 1998; Johnson, 1993; Lickfeldt et al., 2001)

TE is a commonly used turfgrass PGR that suppresses laminar cell elongation by

Received for publication 21 Jan. 2003. Accepted for publication 10 Sept. 2003. Contribution from the Illinois Agricultural Experiment Station. This study was partially supported by the Illinois Turfgrass Foundation.

'Corresponding author; e-mail fermo@uiuc.edu. inhibiting the $3-\beta$-hydroxylase conversion of gibberellic acid-20 to the physiologically-active GA $_{1}$ (Adams et al., 1992). TE appears to offer a management option that reduces vertical shoot growth without reductions in turf quality (Fagerness and Penner, 1998; Johnson, 1993). Fagerness and Penner (1998) observed a $36 \%$ reduction in creeping bentgrass growth for up to 4 weeks after an application of TE at $0.38 \mathrm{~kg} \cdot \mathrm{ha}^{-1}$.

Total nonstructural carbohydrates (TNC) in grasses provide a reservoir of energy in plants beyond the immediate requirements for plant growth and maintenance (Hull, 1992). These reserves are particularly important to the heat tolerance of cool-season turfgrass (Hull, 1992) and the winter survival of warm-season turfgrass (Fry et al., 1993). TNC has been described as a physiological measure of stress tolerance (Beard, 1973; Sheffer et al., 1979, Watschke et al., 1972, 1973). They are also important for plant hardiness and recuperation from injury
(Howard and Watschke, 1991; Hull, 1992; Xu and Huang, 2003).

Previous studies (Goss et al., 2002; Qian and Engelke, 1999) have shown that a TE application increased TNC for various species grown in reduced light conditions, but no studies have examined TE on TNC of creeping bentgrass at fairway heights in full sun. Carbohydrate concentrations were not effected by applications of TE in several other studies conducted under moderate to full sunlight. In a greenhouse study, Qian et al. (1998) observed an increase in TNC in 'Diamond' Zoysiagrass (Zoysia matrella (L.) Merr.) grown under 20\% or less ambient light while no effect was found on plants grown under $60 \%$ natural sunlight. Total nonstructural carbohydrates in tall fescue (Festuca arundinacea Schreb.) leaves or crowns was unaffected by a single application of TE at $0.29 \mathrm{~kg} \cdot \mathrm{ha}^{-1}$ (Richie et al., 2001). In a greenhouse study, Han et al. (1998) observed reduced TNC for up to 14 weeks in 'Penncross' creeping bentgrass verdure treated with TE.

Turfgrasses maintained on golf course fairways receive frequent and close mowings as a common practice. These unfavorable growth conditions may reduce TNC reserves that are essential for turf regrowth. Recreational turfs are often stressed by heavy foot and vehicular traffic. Beard (1973) describes traffic injury as the combination of damage from wear (abrasion of leaf and stem tissue) and compaction (increased soil density). Carroll and Petrovic (1991) used a tire with a smooth surface to simulate vehicle traffic on creeping bentgrass greens. They estimated up to a $47 \%$ loss in turf surface in a 2-year study. Younger (1961) found bentgrass to be relatively intolerant of wear stress. Kohlmeier and Eggens (1983) found up to a $39 \%$ decrease in stolen and leaf production in creeping bentgrass subjected to wear stress.

In a study examining the interaction between TE and traffic stress, Ervin and Koski (2001) observed reduced quality in a Kentucky bluegrass turf receiving traffic whether it also received an application of TE or not.

The TNC content along with visual quality, of a cool-season turf was significantly reduced as a compaction treatment increased (Carrow, 1980). Use of growth retardants on turfs subjected to heavy traffic may have additional detrimental effects on the turf stand. Therefore, the influence of TE on TNC levels should be considered for the health of the turf.

Objectives of this field study were to 1) determine if TE affects TNC content and turf quality of creeping bentgrass at fairway height in full sun at various application frequencies and rates and 2) investigate any interactions between the effects of TE and traffic on TNC content.

\section{Materials and Methods}

Two experiments were conducted. The first experiment was performed from 12 June to 16 Oct. 1995 and the second experiment started 30 May and ended 3 Oct. 1996. Separate, wellestablished turf areas were chosen each year. The turf for each experiment was a mature stand 
of 'Pennlinks' creeping bentgrass with minimal thatch grown on a Flanagan silt loam soil (fine, montmorillonitic, mesic aquic argiudoll) at the University of Illinois Landscape Horticulture Research Facility, Urbana, Ill. Individual plot size was $1.8 \times 0.9 \mathrm{~m}$ with five replications in 1995 and $2.4 \times 1.2 \mathrm{~m}$ with five replications in 1996. The bentgrass plots received $\mathrm{N}$ at $123 \mathrm{~kg} \cdot \mathrm{ha}^{-1}$ as urea during the course of both experiments. Plots were irrigated as needed to prevent moisture stress. Fungicides were applied on a curative basis when required. The bentgrass was maintained at a height of $1.9 \mathrm{~cm}$ by mowing 2 to 3 times weekly with a walking reel mower. Clippings were collected and removed.

TE and traffic treatments. TE was applied using a $\mathrm{CO}_{2}$ powered backpack sprayer at a pressure of $207 \mathrm{kPa}$. All treatments were applied with $467 \mathrm{~L} \cdot \mathrm{ha}^{-1}$ of water. Treatments applied on an active ingredient basis included 1) a single application at $\left.0.28 \mathrm{~kg} \cdot \mathrm{ha}^{-1}, 2\right) \mathrm{re}-$ peated application at a 2 week interval at 0.06 $\left.\mathrm{kg} \cdot \mathrm{ha}^{-1}, 3\right)$ repeated application at a 4 week interval at $\left.0.09 \mathrm{~kg} \cdot \mathrm{ha}^{-1}, 4\right)$ repeated application at a 4 week interval at $0.28 \mathrm{~kg} \cdot \mathrm{ha}^{-1}$, and 5) an untreated control. All TE treatments were only applied during the first 8 weeks of each experiment. Thus, the turf was subjected to three total applications in the case of an every 4-week application and five total applications with the every 2-week application during an 8week period. Each plot received a total of 0.28 $\mathrm{kg} \cdot \mathrm{ha}^{-1}$ within the 8 -week period, including the single application, except for the every 4-week application at $0.28 \mathrm{~kg} \cdot \mathrm{ha}^{-1}$, which received a total of $0.84 \mathrm{~kg} \cdot \mathrm{ha}^{-1}$. The single application rate of $0.28 \mathrm{~kg} \cdot \mathrm{ha}^{-1}$ was the labeled rate for fairway height bentgrass in 1994 and has since been reduced. Plots not receiving TE and/or traffic were included as controls. Treatments were arranged in a strip-plot design with TE applications as whole plots and traffic treatments as strip-plots.

Traffic treatments began at 2 weeks (1995) and 2 d (1996) after initial applications and continued until the last evaluation date. Traffic treatments consisted of 4 passes of a $102.2 \mathrm{~kg}$ smooth roller, $2 \mathrm{~d} \cdot$ week $^{-1}$, for a total of eight passes week ${ }^{-1}$ in 1995 and eight passes daily (Monday through Friday) in 1996. Traffic passes were increased 5-fold in 1996 to increase stress. If soil conditions were too wet for traffic treatments, then passes were added at the earliest possible date to make up the required passes. Bulk density of the top $5 \mathrm{~cm}$ of soil was measured with 16 soil cores from trafficked and nontraffic area, respectively, to determine the degree of compaction.

Turf quality ratings. Turf quality was rated visually on 2-week intervals beginning 2 weeks after the initial application and continuing through the end of study (10 weeks after the last application). Quality was subjectively rated as the average uniformity of color, density, and leaf texture based on a scale of 1 to 9 , with 1 = completely brown turf, 6 $=$ minimum acceptable quality with moderate discoloration, and $9=$ ideal turf with no leaf discoloration or injury.

Plant harvest for TNC determination. Core turf samples were harvested from each plot before initial TE applications and thereafter at 2-week intervals for 18 weeks to provide material for carbohydrate analyses. Two random samples were collected from each treatment with a cup cutter $(10.2 \mathrm{~cm}$ in diameter). The verdure was cut from the root system below the crown before washing. Verdure was washed free of soil over a 1.5-mm mesh screen. All washed tissues were dried first for $1 \mathrm{~h}$ at 100 ${ }^{\circ} \mathrm{C}$ in a forced-air oven and then at $70{ }^{\circ} \mathrm{C}$ for $48 \mathrm{~h}$ before their dry weights were recorded. All tissue samples were ground to pass a 40 mesh screen in a cyclone sample mill (Udy Corp., Fort Collins, Colo.) and stored at $-15^{\circ}$ $\mathrm{C}$ until they were analyzed for TNC.

Carbohydrate quantification. Glucose, fructose, sucrose, and fructan analyses were performed as described in Westhafer et al. (1982). A simplified description of this set of procedures follows. A single aqueous extraction method was used for quantification of glucose, fructose, sucrose, and fructan from the creeping bentgrass tissue. About $60 \mathrm{mg}$ of finely ground tissue was added to a $0.1 \mathrm{M}$ phosphate buffer ( $\mathrm{pH}$ 5.4) and shook at room temperature for $24 \mathrm{~h}$. Free reducing sugars were analyzed according to the method originally developed by Nelson (1944). Glucose content was determined by further reaction with glucose oxidase. A similar extraction procedure was used for sucrose determination using invertase instead of glucose oxidase. Fructan concentration was determined by a method originally outlined by Roe (1934). Reducing sugars (glucose and fructose) and sucrose were determined by absorbance at $540 \mathrm{~nm}$ using a UV-visible spectrophotometer (Shimadzu Instruments Corp., Inc., Ill.). Fructan absorbance was determined at $490 \mathrm{~nm}$. The data are presented based on TNC, which was the sum of free reducing sugars, sucrose, and fructan.

Since an analysis of variance (ANOVA) of all data indicated a significant date by treatment interaction, separate ANOVA were performed for each harvest date to determine treatment

Table 1. Trinexapac-ethyl (TE) effect on turf quality of creeping bentgrass verdure in 1995 and 1996 field studies.

\begin{tabular}{|c|c|c|c|c|c|c|c|c|c|}
\hline \multirow{2}{*}{$\begin{array}{l}\text { Application } \\
\text { interval }\end{array}$} & \multirow{2}{*}{$\begin{array}{c}\text { Application rate (a.i.) } \\
\left(\mathrm{kg} \cdot \mathrm{ha}^{-1}\right)\end{array}$} & \multicolumn{8}{|c|}{ Time after initial application (weeks) } \\
\hline & & 2 & 4 & 6 & $8^{\mathrm{Z}}$ & 10 & 12 & 14 & 16 \\
\hline \multicolumn{10}{|l|}{1995} \\
\hline Untreated & --- & 9.0 & 8.8 & 9.0 & 9.0 & 9.0 & 8.5 & 8.3 & 8.8 \\
\hline Every 4 weeks $^{\mathrm{Y}}$ & 0.28 & 7.8 & 7.8 & 8.0 & 9.0 & 8.6 & 8.8 & 8.8 & 8.8 \\
\hline Every 2 weeks & 0.06 & 9.0 & 8.3 & 8.9 & 8.6 & 9.0 & 9.0 & 8.7 & 9.0 \\
\hline Every 4 weeks & 0.09 & 8.8 & 8.8 & 8.7 & 9.0 & 9.0 & 8.8 & 8.7 & 8.8 \\
\hline $\operatorname{LSD}_{(0.05)}$ & & 0.4 & 0.5 & 0.4 & 0.3 & 0.3 & NS & 0.6 & NS \\
\hline $\operatorname{LSD}_{(0.05)}$ & & NS & 0.1 & 0.1 & NS & NS & NS & NS & NS \\
\hline TE & & $* *$ & $* *$ & $* *$ & $* *$ & $* *$ & NS & $*$ & NS \\
\hline Traffic & & NS & ** & $* *$ & NS & NS & NS & NS & NS \\
\hline $\mathrm{TE} \times$ traffic & & NS & NS & NS & NS & NS & NS & NS & NS \\
\hline \multicolumn{10}{|l|}{1996} \\
\hline Untreated & --- & 9.0 & $9.0^{\mathrm{x}}$ & $8.8^{\mathrm{x}}$ & 8.6 & $8.6^{x}$ & 8.4 & 8.1 & 8.3 \\
\hline Single application & 0.28 & 6.8 & 7.1 & 8.9 & 8.8 & 9.0 & 8.4 & 8.1 & 8.4 \\
\hline Traffic $^{(0.05)}$ & & 7.6 & 7.6 & 7.5 & 8.3 & 7.8 & 8.5 & 7.7 & 8.1 \\
\hline No traffic & & 8.1 & 8.5 & 8.5 & 8.7 & 8.6 & 8.6 & 8.6 & 8.8 \\
\hline $\operatorname{LSD}_{(005)}$ & & 0.2 & 0.3 & 0.2 & 0.1 & 0.3 & NS & 0.1 & 0.2 \\
\hline $\mathrm{TE} \quad(0.05)$ & & $* *$ & $* *$ & $* *$ & NS & $* *$ & NS & NS & $*$ \\
\hline Traffic & & $* *$ & $* *$ & $* *$ & $* *$ & ** & NS & $* *$ & $* *$ \\
\hline $\mathrm{TE} \times$ traffic & & NS & $*$ & $*$ & NS & $* *$ & NS & NS & NS \\
\hline
\end{tabular}

${ }^{\mathrm{i}}$ Final week of all applications.

${ }^{y}$ Every 2 weeks, applications were applied five times at $0,2,4,6$, and 8 weeks after treatment (WAT). Every 4 weeks, applications were applied three times at 0,4 , and 8 WAT.

${ }^{\mathrm{x}}$ Means of nontrafficked treatments only. 
effects. Fisher's protected least significant difference (LSD) values were generated to separate treatment means. Significant means were separated at $P \leq 0.05$. The results of TE treatments listed in Table 1 for 4, 6, and 10 weeks after treatment (WAT) in 1996 were limited to the nontrafficked plots only due to a significant interaction between traffic and TE application treatments.

\section{Results and Discussion}

Turfgrass quality. The quality of the creeping bentgrass was significantly influenced by application rates and intervals in both years. Single applications of TE at $0.28 \mathrm{~kg} \cdot \mathrm{ha}^{-1}$ significantly reduced turf quality for 4 weeks in both experiments. Sequential applications of $\mathrm{TE}$ at $0.06 \mathrm{~kg} \cdot \mathrm{ha}^{-1}$ exhibited reduced quality compared to the control at week 4 and 8 in 1995 and week 2 in 1996 . The same treatments in 1996 also showed a significant increase in quality at 16 weeks after the initial treatment. Sequential applications of TE at $0.09 \mathrm{~kg} \cdot \mathrm{ha}^{-1}$ every four weeks reduced turf quality in 1996 for up to 6 weeks.

Sequential applications of TE at 0.28 $\mathrm{kg} \cdot \mathrm{ha}^{-1}$ reduced quality for up to 10 weeks after the initial application in both years. This was probably a reflection of an excessive total application rate $\left(0.84 \mathrm{~kg} \cdot \mathrm{ha}^{-1}\right)$. Wu et al. (1976) reported a single application at a high rate of maleic hydrazide [1,2-dihydro3,6-pyridazine-dione], chlorflurenol (methyl2-chloro-9-hydroxyfluorene-9-carboxylate, methyl-9-hydroxy fluorene-9-carboxylate) or mefluidide [N-[2,4-dimethyl-5-[[(trifluor omethyl)sulfonyl]amino]phenyl]acetamide] frequently caused discoloration or injury of bermudagrass, while split applications at low rates provided good growth retardation with no injury.

Total nonstructural carbohydrates. Field application of TE showed a similar effect on the TNC content of creeping bentgrass as described in previous greenhouse studies (Han et al., 1998). When TE was applied once at $0.28 \mathrm{~kg} \cdot \mathrm{ha}^{-1}$, there was a significant reduction in TNC at 4, 6 and 10 WAT in 1995 and 4 to 10 WAT in 1996 (Table 2). In 1996 when applications were repeated at 2 and 4 week intervals at 0.06 and $0.09 \mathrm{~kg} \cdot \mathrm{ha}^{-1}$, respectively, TEresulted in the reduction of TNC from week 8 to week 14. After 14 weeks, the TNC content showed an increase for 4 weeks. The reduction of TNC over time was observed at higher application rates and lasted long after the final application. Bentgrass treated with TE every 4 weeks at $0.28 \mathrm{~kg} \cdot \mathrm{ha}^{-1}$ had significantly less TNC than untreated controls until 16 weeks into each experiment.

Traffic effects. A significant interaction between traffic and TE treatments was only observed in $13 \%$ of the analyses of all measurements. Traffic affected turf quality in 1995 only during initial growth reduction between weeks 4 and 6. In 1995, no TE by traffic interactions in quality were observed. Turfs subjected to the greater traffic forces in the 1996 experiment had significantly lower quality than turf on nontrafficked soils for all evaluations. While turf quality was lower on trafficked plots in 1996, it was rated commercially acceptable on all dates.

There was no interaction between traffic treatments and TE applications in the verdure TNC in either year. The more moderate compaction treatment in 1995 did not lower verdure TNC content. In 1996, with more compacting action, verdure TNC content was significantly lower in plots receiving compaction from weeks 4 to 18 .

Bulk density in the top $5 \mathrm{~cm}$ of soil significantly increased from 1.06 to $1.12 \mathrm{~g} \cdot \mathrm{cm}^{-3}$ in 1995 and from 1.15 to $1.20 \mathrm{~g} \cdot \mathrm{cm}^{-3}$ in 1996 , when traffic was applied (data not shown). Soil moisture retention among treatments did not differ (data not shown). The level of bulk density in this study is relatively low compared with common turf sites, so we considered the smooth roller application a simulation of tire traffic rather than a compacting force. Hummel (1995) stated that most turf soils have bulk densities of 1.4 to 1.6 .

Single TE applications reduced bentgrass growth for at least 4 weeks (data not shown) with minor loss in turf quality. However, reduction in TNC in verdure compared to untreated plots was often observed from week 4 to 10 in both experiments. In late August (wk 12), TNC content in the single TE application plots was not different from the untreated turf and remained so for the duration of the experiments.

While the turf response to single TE applications might have been the result of the relatively high single rate, a similar response was observed for plots receiving multiple lower rate applications. Plots receiving biweekly applications of TE at $0.06 \mathrm{~kg} \cdot \mathrm{ha}^{-1}$, in 1996 had lower verdure TNC content compared to untreated turf from week 8 to 14 . The 14 week evaluation was 6 weeks after the final application at the $0.06 \mathrm{~kg} \cdot \mathrm{ha}^{-1}$ rate, which was similar to the response of turf receiving single applications. Turf quality on plots receiving the $0.06 \mathrm{~kg} \cdot \mathrm{ha}^{-1}$ rate was initially reduced during the first four weeks similar to turf receiving single $0.28 \mathrm{~kg} \cdot \mathrm{ha}^{-1}$ applications. Sequential rate applications generally did not exhibit

Table 2. Trinexapac-ethyl (TE) effect on total nonstructural carbohydrates of creeping bentgrass verdure in 1995 and 1996 field studies.

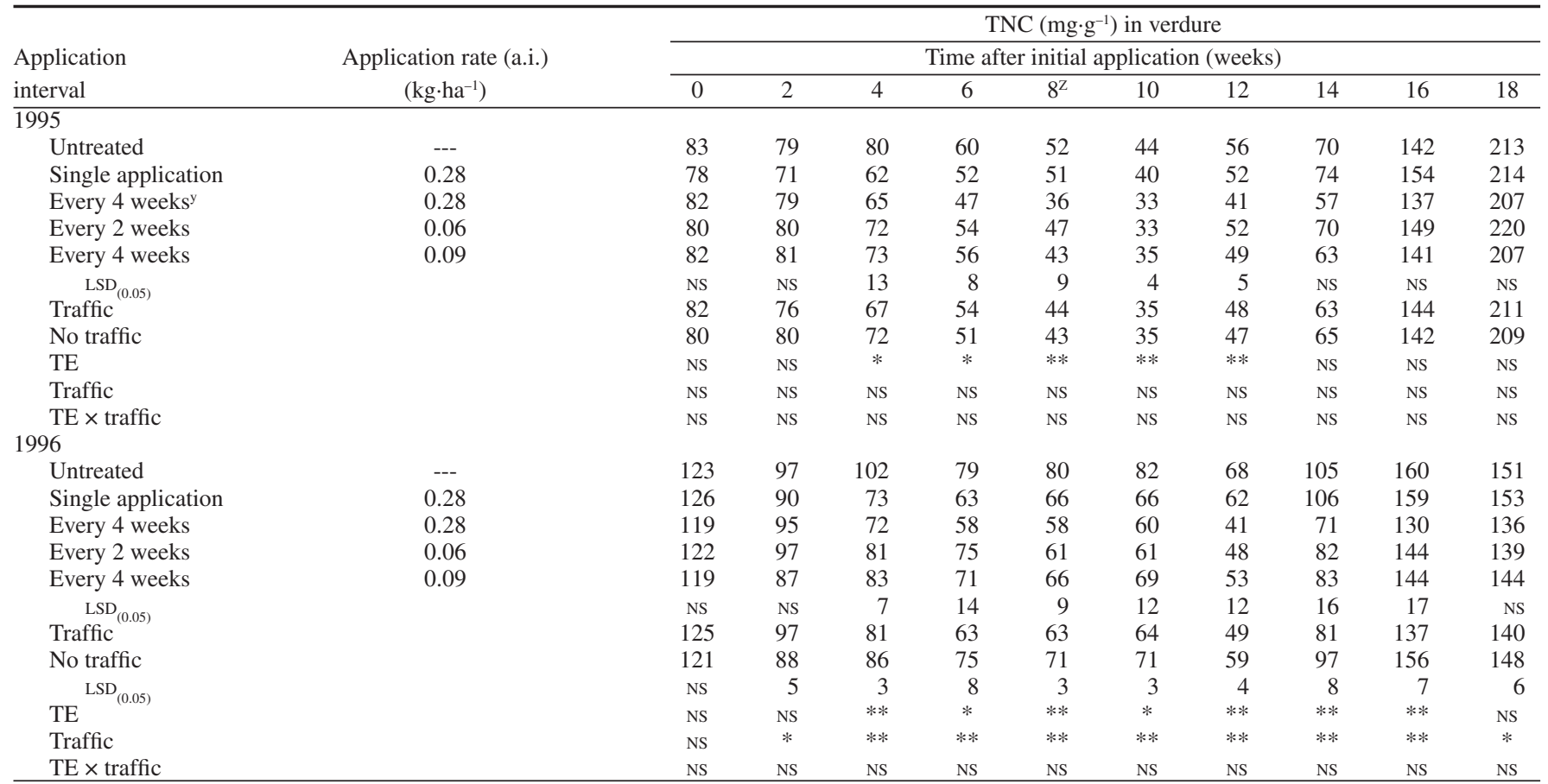

${ }^{2}$ Final week of all applications.

${ }^{y}$ Every 2 weeks, applications were applied five times at 0,2, 4, 6, and 8 weeks after treatment (WAT). Every 4 weeks, applications were applied three times at 0,4 , and 8 WAT. 
reduced quality after week 4 while reducing clipping production for up to 10 weeks (data not shown).

While initial applications of TE in this study occurred in late spring, $\approx 15$ to $30 \mathrm{~d}$ after normal golf course TE applications in Illinois, most golf course superintendents continue sequential applications throughout the growing season to maintain high turf quality with a reduction of mowing requirements as a secondary objective. Since TNC levels have been observed to be lowest during the hotter months of the growing season, this would be a time when TNC reduction might be most detrimental. Average seasonal TNC concentrations measured in this study were similar to those reported by Sweeney et al. (2001) and $\mathrm{Xu}$ and Huang (2003). Several investigators have studied the impact of TE on TNC for a variety of turfs grown under reduced light $(80 \%$ shade or greater) (Goss et al., 2002; Qian and Engelke, 1999; Qian et al., 1998; Stier and Rogers, 2001). While each of these studies found an increase in TNC for turfs treated with $\mathrm{TE}$, this may be a phenomenon restricted to the low light environment. Studies conducted in $60 \%$ or greater ambient light (Qian et al., 1998; Richie et al., 2001) observed no effect on TNC or up to a $45 \%$ reduction (Han et al., 1998) in TNC concentrations. Except for the present study, no field evaluation of the effect of TE on verdure TNC concentrations has been conducted in full sun for creeping bentgrass. In a previous greenhouse study (Han et al., 1998), reduced TNC concentrations were observed on TE treated bentgrass grown under supplemental lighting $\left(300 \mu \mathrm{mol} \cdot \mathrm{m}^{-2} \cdot \mathrm{s}^{-1} \mathrm{PAR}\right)$.

These results suggest that the high rates of TE (over twice the current labeled rate) applied in this study, either sequential or single applications, might reduce turf quality or carbohydrate content. Weather patterns over the experimental site were similar for both years with seasonally average temperatures and rainfall. Correlation analyses between turf quality and TNC content indicated no significant correlations. While this study did not examined if any temporary reduction in turf quality or TNC was detrimental to the turf, multiple TE applications at the low rate (0.06 $\mathrm{kg} \cdot \mathrm{ha}^{-1}$ ) may minimize any TNC or quality reduction while providing effective growth suppression for extended periods.

\section{Literature Cited}

Adams, R., E. Kerber, K. Pfister, and E.W. Weiler. 1992. Studies on the action of the new growth retardantCGA 163'935 (cimectacarb), p. 818-827. In: C.M. Karssen et al. (eds.). Progress in plant growth regulation. Kluwer Academic Publ., Dordrecht, The Netherlands.

Beard, J.B. 1973. Turfgrass science and culture. Prentice Hall, Englewood Cliffs, N.J.

Beard, J.B. 2002. Turf management for golf courses. 2nd ed. Ann Arbor Press, Chelsea, Mich.

Carroll, M.J., and A.M. Petrovic. 1991. Wear tolerance of kentucky bluegrass and creeping bentgrass following nitrogen and potassium application. HortScience 26:851-853.

Carrow, R.N. 1980. Influence of soil compaction on three turfgrass species. Agron. J. 72: $1038-1042$.

Ervin, E.H. andA.J. Koski. 2001. Kentucky bluegrass growth responses to trinexapac-ethyl, traffic, and nitrogen. Crop Sci. 41(6):1871-1877.

Fagerness, M.J., and D. Penner. 1998. Evaluation of V-10029 and trinexapac-ethyl for annual bluegrass seedhead suppression and growth inhibition in five cool-season species. Weed Technol. 12:436-440.

Fry, J.D., N.S. Lang, R.G.P. Clifton, and F.P Maier. 1993. Freezing tolerance and carbohydrate content of low-temperature-acclimated and nonacclimated centipedegrass. Crop Sci. 33(5):1051-1055.

Goss, R.M., J.H. Baird, S.L. Kelm, and R.N. Calhoun. 2002. Trinexapac-ethyl and nitrogen effects on creeping bentgrass grown under reduced light conditions. Crop Sci. 42:472-479.

Han, S.W., T.W. Fermanian, J.A. Juvik, and L.A. Spomer. 1998. Growth retardant effects on visual quality and nonstructural carbohydrates of creeping bentgrass. HortScience 33(7):1197-1199.

Howard, H.F. and T.L. Watschke. 1991. Variable high-temperature tolerance among kentucky bluegrass cultivars. Agron. J. 83:69-693.

Hull, R. 1992. Energy relations and carbohydrate partitioning in turfgrass, p. 175-205. In: D. V. Waddington et al. (eds.). Turfgrass. Agron. Monogr. vol. 32. ASA-CSSA-SSSA, Madison, Wis.

Hummel, Jr., N.W. 1995. Assess soil condition on site. Grounds Maint. 30(6):22, 24, 28.

Johnson, B.J. 1993. Frequency of plant growth regulator and mowing treatments: Effects on injury and suppression of centipedegrass. Agron. J. 85:276-280.
Kohlmeier, G.P., and J.L. Eggens. 1983. The influence of wear and nitrogen on creeping bentgrass growth. Can. J. Plant Sci. 63:189-193.

Lickfeldt, D.W., D.S. Gardner, B.E. Branham, and T.B. Voigt. 2001. Implications of repeated trinexapac-ethyl applications on kentucky bluegrass. Agron J 93:1164-1168.

Nelson, N. 1944. A photometric adaptation of the Somogyi method for the determination of glucose. J. Biol. Chem. 153:375-380.

Qian, Y. and M. Engelke. 1999. Influence of trinexapac-ethyl on Diamond zoysiagrass in a shade environment. Crop Sci 39:202-208.

Qian, Y.L., M.C. Engelke, M.J.V. Foster, and S. Reynolds. 1998. Trinexapac-ethyl restricts shoot growth and improves quality of diamond zoysiagrass under shade. HortScience 33: 1019-1022.

Richie, W.E., R.L. Green, and F. Merino. 2001 Trinexapac-ethyl does not increase total nonstructural carbohydrate content in leaves, crowns, and roots of tall fescue. HortScience 36:772-775.

Roe, J.H. 1934. A colorimetric method for the determination of fructose in blood and urine. J. Biol. Chem. 107:15-22.

Sheffer, K.M.,T.L. Watschke, and J.M. Duich. 1979. Carbohydrate sampling in kentucky bluegrass turf. Agron. J. 71:301-304.

Stier, J.C. and J.N. Rogers, III. 2001. Trinexapacethyl and iron effects on supina and kentucky bluegrasses under low irradiance. Crop Sci 41: 457-465.

Sweeney, P., K. Danneberger, and D. Wang. 2001 Root weight, nonstructural carbohydrate content, and shoot density of a high-density creeping bentgrass cultivars. HortScience 36:368-370.

Watschke, T.L., R.L. Schmidt, E.W. Carson, and R.E. Blaser. 1972. Some metabolic phenomena of kentucky bluegrass under high temperature. Crop Sci. 12:87-90.

Watschke, T.L., R.L. Schmidt, E.W. Carson, and R.E. Blaser. 1973. Temperature influence on the physiology of selected cool season turfgrasses and bermudagrass. Crop Sci. 13:591-594.

Westhafer, M.A., J.T. Law, Jr., and D.T. Duff. 1982 Carbohydrate quantification and relationships with $\mathrm{N}$ nutrition in cool-season turfgrass. Agron. J. 74:270-274.

Wu, C., H.R. Myers, and P.W. Santelmann. 1976. Chemical retardation of bermudagrass turf. Agron. J. 68:949-952.

Xu, Q., and B. Huang. 2003. Seasonal changes in carbohydrate accumulation for two creeping bentgrass cultivars. Crop Sci. 43:266-271.

Youngner, V.B. 1961. Accelerated wear tests on turfgrasses. Agron. J. 53:217-218. 